\title{
Collaborative Learning Technique within Higher Learning Education Students
}

\author{
Mohd Aderi Che Noh, Sri Andayani Mahdi Yusuf \\ Faculty Education, Universiti Kebangsaan Malaysia, Bangi, Malaysia \\ Email: aderi@ukm.edu.my
}

How to cite this paper: Noh, M. A. C., \& Yusuf, S. A. M. (2018). Collaborative Learning Technique within Higher Learning Education Students. Creative Education, 9, 23672375. https://doi.org/10.4236/ce.2018.914177

Received: August 16, 2018

Accepted: October 28, 2018

Published: October 31, 2018

Copyright $\odot 2018$ by authors and Scientific Research Publishing Inc. This work is licensed under the Creative Commons Attribution International License (CC BY 4.0).

http://creativecommons.org/licenses/by/4.0/

(c) (i) Open Access

\begin{abstract}
Collaborative learning assured in producing high quality and competitive students. Previous researches' findings figured out that high quality students were able to master various fields of knowledge, experts in solving problems based on factual supports and also a good speaker. In order to do so, the students should identify the exact style of learning. This observation research applied Grasha Learning Style Model, by using a set of questionnaire as the research's instrument. 221 students have involved as the respondents for this research. The findings of this result showed that collaborative learning style had been identified as one of the most effective learning style for students. This research also discusses about the advantageous of applying collaborative learning style of learning towards the process of teaching and learning within the high level education institute, in detail. Collaborative learning style is expected to be a guide for the students to share knowledge and sprout their mind in order to ensure an active learning and effective learning process.
\end{abstract}

\section{Keywords \\ Collaborative, Collaborative Learning Style, Active Learning, Teaching}

\section{Introduction}

The collaborative concept refers to a group of students who cooperate towards achieving the goal that they have agreed together (Baharin \& Yusop, 2011). Collaborative learning style is known as a method applied by the students in gathering certain knowledge. Throughout the collaborative learning style, students would be able to give and accept helps from their friends. This effort is important for the students to build confidence in solving various issues occur within their education scope. A brilliant individual should possess the latest technology 
ability, able to solve problems based on facts, think creative and innovatively, intelligent in managing ICT application, fluent speaker and also a smart debater. Such abilities are the most important assets required in developing the country (Bakar \& Iksan, 2015). Thus, the students are the nation's target in achieving success as well as the Nation's Education Philosophy towards bringing the country to become a well-known developed country.

\section{Research Background}

Islamic Education is one of the compulsory subjects that all Muslim students should acquire and learn in any education institutes in Acheh. Throughout the teaching of Islamic Education, our live would be much organized and does not strayed away from the right path as stated by the religion. Islamic Education plays a huge role in instilling soul and spirituality building for every individual in order to be a perfect Muslim.

Students-centered learning (SCL) is an education approach whereby curriculum, teaching activities, learning and evaluation are focuses on the students (Md Nawi, 2011). SCL is a wide learning approach as it consists of active learning experience, creative and critical problem solving, simulation and role play, case research, self learning, collaborative and cooperative learning ( $\mathrm{Md}$ Nawi, 2011). Active learning is the form of any situations and factors by which students participate actively in the process of $\mathrm{T} \& \mathrm{~L}$, be it through interaction within the students or the interactions with the teachers.

Collaborative and cooperative learning are the general concept which refers to one group learning experience which could occur within peers in a tutorial set or faculty students from any short term projects researches for each group in a class (Jasmi, Ibrahim, \& Ilias, 2012). Cooperative learning refers to learning process that occurs throughout cooperation of a group of students, usually in the classroom (Sang, 2011).

According to (Jasmi, Ibrahim, \& Ilias, 2012), to success in any form of group learning which requires cooperation, the students should be equipped with two attitudes which is first, they should create an attitude of relying positive vibes among themselves, by cooperating to finish their tasks. Secondly, everyone should be encouraged to fulfill their responsibilities towards each members in the group, by which every member's contribution towards the group effort should be measured.

\section{Problem Statement}

Lately, a provocation occur regarding the need of learning strategy transition especially in Higher Education Institution (Md Nawi, 2011). He stated that the traditional method (anything related to teachers-oriented teaching) are no longer the best method to equipped students with various skills. A few seminars had been conducted such as Problem-Based Learning seminar conducted by University Malaya, International Conference on Learning and Teaching by University 
Technology Malaysia, 3rd International Workshop on Self-Learning Material Development by Universiti Sains Malaysia and 4th International Conference on Learner Diversity (ICELD, 2014) by Universiti Kebangsaan Malaysia. Now all the Higher Education Institutioan in Private University are required to switch to students-centered learning (SCL). SCL has been implemented in the advanced country with various calls such as Student-Centred Instruction (Felder \& Brent, 1996) or Learner-Centred Instruction (Newby, Stepich, Lehman, \& Russell, 2000), which still bring the same meaning.

It is known that every student have their own different way of learning. These differences insist the educators to consider the students' needs, abilities, determinations and tendencies by varying the sources and teaching methods. This is in line with the opinions of (Amir, 2008; Mahamod, Yusoff, \& Ibrahim, 2009), who stated that classroom teaching and learning practice would be more meaningful if it suits the teacher's teaching styles and the students' learning styles. According to UNICEF (2000), a high quality education is a process which not only focusing on the classroom learning process, but also related to the students themselves, teachers, students' environments as well as their achievement. (Butch \& Bartley, 2002; Guolla, 1999; Wilson \& Lizzio, 1997) stated that an effective learning are not only induced by the teachers' skills and expertance, but also influenced by the strategies they used.

In collaborative learning style, students can give and receive helps from their friends in sharing the information. This is equivalent to (Hong, $\mathrm{Yu}, \& \mathrm{Chen}$, 2011) who stated that throughout the implementation of collaborative learning style, students would be able to share knowledge and solve contradictions between their perspectives by giving and receiving helps from each other. Thus, collaborative learning method helps students to explore learning method be it through the sharing of information, communicating, conduct observation, surveillance and information processing, which should be solved together.

\section{Objectives}

In detail, this research is conducted to identify the collaborative learning style practiced by the students which could lead to an active, fun, interesting and beneficial learning process.

\section{Conceptual Research Plan}

Grasha Learning Style Inventory (1996) is used to measure the collaborative learning style. Grasha (1996) defined learning style as self quality that influenced a student's ability in receiving information, acquiring knowledge, interact with teachers and students as well as involving themselves into the process of teaching and learning. According to Grasha, learning style is determined by a few factors such as students' method of processing information, social interaction and environment. In addition to that, Grasha stated that learning style is a part of an individual personality consisting of goals, emotion, desire and attitude to- 
wards the learning method.

Grasha (1996) stated that basically, a student would apply all the following learning styles in the process of teaching and learning. They have the tendency to apply more than one method in gaining acknowledge. Grasha also listed out a few ideal learning styles, which are independent learning, collaborative and self involving. According to Grasha, the depending, avoiding and competiting learning styles are less suitable to be practised in the teaching and learning process. This inventory is trustable as it had been widely used by other researchers such as (Amir, 2008; Ibrahim, 2006; Amir, 2007; Razak \& Azman, 2012; Babadogan \& Kilic, 2012; Bayrak, 2012; Triman, 2014; Yusuf, 2016).

\section{Research Methodology}

This research is a quantitative research which applied observation method, descriptively conducted in Universities Islam Negeri Ar-Raniry, Aceh. A total of 483 had been identified as a population and only 221 students involved as the sample. Researcher apply a simple random technique and determining the sample based on the (Krejcie \& Morgan, 1970) formula.

This research used questionnaire instrument based on Grasha Learning Style Model (1996). The Alpha Cronbach value received by all of the collaborative learning style items from the research is 0.906 . This value shows that the questionnaire items has high reliability and it can be used as the sample of this research. Statistical Package for the Social Science (SPSS) version 22.0 is used to analyse this research with the guideline of mean, frequency, standard deviation and percentage (Table 1).

This analysis description is elaborated by dividing it into the learning style aspects such as independent, avoidant, collaborative, dependent, competitive and participant learning styles. However, this research is only focusing on collaborative learning only.

\section{Findings}

The respondents of this research consists of 1 st, 2nd and 3rd year students from Education Faculty (Fakultas Tarbiyaj) in UIN Ar-Raniry Aceh. A total of 221

Table 1. Learning Style Score Interpretation.

\begin{tabular}{cccc}
\hline Learning Style & Low Score & Middle Score & High Score \\
\hline Independent & $1.0-2.7$ & $2.8-3.8$ & $3.9-5.0$ \\
Avoidant & $1.0-1.8$ & $1.9-3.1$ & $3.2-5.0$ \\
Collaborative & $1.0-2.7$ & $2.8-3.4$ & $3.5-5.0$ \\
Dependent & $1.0-2.9$ & $3.0-4.0$ & $4.1-5.0$ \\
Competitive & $1.0-1.7$ & $1.8-2.8$ & $2.9-5.0$ \\
Participant & $1.0-3.0$ & $3.1-4.1$ & $4.2-5.0$ \\
\hline
\end{tabular}

Source: Grasha (1996). 
students involved in this research, who were taking Islamic Education courses. The findings shown that there were 69 (31.2\%) male students and 152 (68.8\%) female students, which shows that there were more female respondents in comparison to male.

The descriptive analysis consists of mean, percentage and standard deviation which are used in determining the students' collaborative learning style level. The outcome were as stated in Table 2.

Table 2 shows the distribution of frequencies, percentages, standard deviations and means of the students' collaborative learning styles items. Overall, collaborative learning style is practiced in the highest level, which is within the range of 3.57 until 4.53. The highest item is "students should be encouraged to share opinion with their friends" ( mean $=4.53$ and sd $=0.71$ ). This shows that, majority of the students (135 students, $61.1 \%$ ) agreed that their opinions should be shared with their friends.

In terms of frequencies and percentages, a number of 135 students (61.1\%) are strongly agree, 77 students (34.8\%) agree, 4 students (1.8\%) quite disagree, 3 students $(1.4 \%)$ strongly disagree, whilst only 2 students $(0.9 \%)$ chooses disagree. Overall, the collaborative learning style practiced is within the high level $($ mean $=4.13$ and $\mathrm{sd}=0.37)$.

Table 2. Students' collaborative learning style level.

\begin{tabular}{|c|c|c|c|c|c|c|c|c|c|}
\hline No. & Item & SD & $\mathrm{D}$ & QD & A & SA & Mean & $\mathrm{SD}$ & Interpretation \\
\hline 1 & $\begin{array}{l}\text { Cooperating with friends while } \\
\text { conducting activities is fun }\end{array}$ & $\begin{array}{c}6 \\
(2.7 \%)\end{array}$ & $\begin{array}{c}3 \\
(1.4 \%)\end{array}$ & $\begin{array}{c}11 \\
(5.0 \%)\end{array}$ & $\begin{array}{c}110 \\
(49.8 \%)\end{array}$ & $\begin{array}{c}91 \\
(41.2 \%)\end{array}$ & 4.25 & 0.84 & High \\
\hline 2 & $\begin{array}{l}\text { I discuss about the courses' } \\
\text { materials with others }\end{array}$ & $\begin{array}{c}4 \\
(1.8 \%)\end{array}$ & $\begin{array}{c}9 \\
(4.1 \%)\end{array}$ & $\begin{array}{c}18 \\
(8.1 \%)\end{array}$ & $\begin{array}{c}126 \\
(57.0 \%)\end{array}$ & $\begin{array}{c}64 \\
(29.0 \%)\end{array}$ & 4.07 & 0.83 & High \\
\hline 3 & $\begin{array}{l}\text { I am having fun listening to my } \\
\text { friends' opinions regarding any } \\
\text { issues discussed in the class }\end{array}$ & 0 & $\begin{array}{c}5 \\
(2.3 \%)\end{array}$ & $\begin{array}{c}17 \\
(7.7 \%)\end{array}$ & $\begin{array}{c}129 \\
(58.4 \%)\end{array}$ & $\begin{array}{c}70 \\
(31.7 \%)\end{array}$ & 4.19 & 0.67 & High \\
\hline 4 & $\begin{array}{l}\text { Students should be encouraged to } \\
\text { share opinions with their friends }\end{array}$ & $\begin{array}{c}3 \\
(1.4 \%)\end{array}$ & $\begin{array}{c}2 \\
(0.9 \%)\end{array}$ & $\begin{array}{c}4 \\
(1.8 \%)\end{array}$ & $\begin{array}{c}77 \\
(34.8 \%)\end{array}$ & $\begin{array}{c}135 \\
(61.1 \%)\end{array}$ & 4.53 & 0.71 & High \\
\hline 5 & $\begin{array}{l}\text { I loved to revise with my friends in } \\
\text { preparation for exams }\end{array}$ & $\begin{array}{c}14 \\
(6.3 \%)\end{array}$ & $\begin{array}{c}24 \\
(10.9 \%)\end{array}$ & $\begin{array}{c}57 \\
(25.8 \%)\end{array}$ & $\begin{array}{c}74 \\
(33.5 \%)\end{array}$ & $\begin{array}{c}52 \\
(23.5 \%)\end{array}$ & 3.57 & 1.15 & High \\
\hline 6 & $\begin{array}{l}\text { The class learning session makes } \\
\text { me feels like we are a team with in } \\
\text { need of each other in learning }\end{array}$ & $\begin{array}{c}5 \\
(2.3 \%)\end{array}$ & $\begin{array}{c}6 \\
(2.7 \%)\end{array}$ & $\begin{array}{c}23 \\
(10.4 \%)\end{array}$ & $\begin{array}{c}136 \\
(61.5 \%)\end{array}$ & $\begin{array}{c}51 \\
(23.1 \%)\end{array}$ & 4.00 & 0.81 & High \\
\hline 7 & $\begin{array}{l}\text { The most important aspect of } \\
\text { learning is the ability to cooperate }\end{array}$ & $\begin{array}{c}1 \\
(0.5 \%)\end{array}$ & $\begin{array}{c}6 \\
(2.7 \%)\end{array}$ & $\begin{array}{c}19 \\
(8.6 \%)\end{array}$ & $\begin{array}{c}136 \\
(61.5 \%)\end{array}$ & $\begin{array}{c}59 \\
(26.7 \%)\end{array}$ & 4.11 & 0.70 & High \\
\hline 8 & $\begin{array}{l}\text { The mastery of materials are both } \\
\text { lecturers' and students' role }\end{array}$ & 0 & $\begin{array}{c}2 \\
(0.9 \%)\end{array}$ & $\begin{array}{c}26 \\
(11.8 \%)\end{array}$ & $\begin{array}{c}106 \\
(48.0 \%)\end{array}$ & $\begin{array}{c}87 \\
(39.4 \%)\end{array}$ & 4.26 & 0.70 & High \\
\hline 9 & $\begin{array}{l}\text { I am ready to help students who } \\
\text { can hardly understand }\end{array}$ & $\begin{array}{c}1 \\
(0.5 \%)\end{array}$ & $\begin{array}{c}3 \\
(1.4 \%)\end{array}$ & $\begin{array}{c}17 \\
(7.7 \%)\end{array}$ & $\begin{array}{c}115 \\
(52.0 \%)\end{array}$ & $\begin{array}{c}85 \\
(38.5 \%)\end{array}$ & 4.27 & 0.70 & High \\
\hline \multirow[t]{2}{*}{10} & $\begin{array}{l}\text { I don't mind conducting } \\
\text { activities in groups }\end{array}$ & $\begin{array}{c}5 \\
(2.3 \%)\end{array}$ & $\begin{array}{c}5 \\
(2.3 \%)\end{array}$ & $\begin{array}{c}23 \\
(10.4 \%)\end{array}$ & $\begin{array}{c}136 \\
(23.5 \%)\end{array}$ & $\begin{array}{c}52 \\
(23.5 \%)\end{array}$ & 4.02 & 0.80 & High \\
\hline & Overall & & & & & & 4.13 & 0.37 & High \\
\hline
\end{tabular}




\section{Discussion}

The item with highest mean is "students should be encouraged to share their opinion with their friends" ( mean $=4.53$ and sd $=0.71$ ). This shows that majority of the students (135 students, $61.1 \%$ ) stated that the sharing of opinions with others is indeed, necessary. Every students has their own opinions in interpreting a certain knowledge. By sharing their opinions, they would be able to sprout their mind in assuring themselves to do something for their task and receiving the benefits, together. By doing so, students would give higher commitment in making decisions, submissing and arguing among themselves. Jasmi, Ibrahim, \& Ilias (2012) stated that discussion allows students to think, identify and give opinions regarding something that they don't know. Through discussion, the classroom environment would be much brighter and easier for all the students to understand any matter discussed.

According to (Grasha, 1996) students who practiced collaborative learning style usually loved working in groups. They prefer conducting a task that involves discussion and group projects. They cooperate, share ideas and knowledge during the learning process. They also prefer any learning process which followed by discussion in small groups or seminars. Hence, lecturers should grab this chance by giving group tasks to the students.

Group tasks always encourage students to develop their academic achievement (Razak \& Azman, 2012; Babadogan \& Kilic, 2012; Bayrak, 2012). The research findings also supports the opinions of (Triman, 2014; Altun \& Yazici, 2010) who stated that smart and intelligent students prefer learning with various activities and required cooperation among themselves, in solving the tasks.

The item of "the mastery of materials are the students and lecturers' role" is $($ mean $=4.26$ and $s d=0.70)$. This shows that a number of 106 students $(48.0 \%)$ agreed that both lecturers and students should mastered the usage of materials used in the discussion. As a teacher, they are the ideal sample of discussing whereas they need to choose wisely, explain and give elaboration or rethorics to undergo the discussion flow in order to strengthen their experience value (Jasmi, Ibrahim, \& Ilias, 2012). In other words, lecturers should challenge their students, but not making them felt threatened, at the same time. Jasmi, Ibrahim, \& Ilias (2012) added that a discussion should be started with a small group. For instance, the teacher could instruct their students to spend a few minutes to discuss a certain topics, questions, cases or issues within a small group, consisting of 3 to 6 students. After that, they will be instructed to present one representative from each group to conclude their discussion. By the end of the lesson, the teacher should simplify all the important points in order to ensure that the students are aware of the correct and wrong opinions. The teachers and students should be well prepared before and while conducting this activity.

The item which has the lowest mean value is "I like to revise with my friends in preparing for examination" ( $m e a n=3.57$ and $s d=1.15$ ). This shows that only 74 students (33.5\%) agreed that they prefer revising with their friends when 
preparing for exams. This could most probably occur because, students in the High Education Level Institute (IPT) prefer learning independently, free from any disturbance while preparing for examination. Only 14 students (6.3\%) who stated strongly disagree. This proven that most of these students prefer independent learning and apply different learning styles in preparing themselves for the examination.

It is concluded that collaborative learning style could encourage students to achieve better in the academic performance. If the students involve themselves in a group discussion, they tend to have better understanding in anything that they have been learning (Halic, Lee, Paulus, \& Spence, 2010).

There are many benefits in practicing collaborative learning style, which are saving time in finishing their task (Amir, 2007), ease in gaining and gathering ideas and abilities from other students (Amir, 2007; Yusuf, 2016; Hasanuddin, 2009). By applying this learning style, students will enjoy their time with friends and thus prefer finishing their tasks together. Collaborative style learners are able to gain knowledge throughout the sharing of ideas and abilities with others. This can be seen from the activities conducted by students who used to exchange ideas and argued their points among themselves.

In addition, (Anitah, 2007) stated that there were many benefits received in applying collaborative learning if the implementation conducted to the maximum. Among the benefits are creating a sense of responsibilities in every individuals, learn to solve the problems together, having the sense of togetherness within the team members, developing courages in voicing out opinions and ideas, or expanding knowledge and experiences within their group members.

In Islam, learning in group could bring various benefits, which it is proclaimed as one of the good deed that will receive high uncounted rewards, as any other deeds such as practicing congregated prayer (solah), sacrificing ceremony and organizing a feast or gatherings. The collaborative learning style is in line with the decree of Allah SWT in Surah Al-Maidah: 5:2, meaning;

"And cooperate in righteous and piety, but do not cooperate in sin and aggression".

(Basmeih, 2001: p. 242)

In this sentence, it is clearly stated that Allah S.W.T enjoin all of the human mankind to interact and cooperate among themselves in practicing good deeds, and prohibit them in practicing bad deeds. This shows that collaboration could have wider and comprehensive meanings, whereby the students would create a relationship with other people in order to achieve their targeted aim. Thus, knowledge sharing is not only limited to either the relationship among students, or students with their lecturers, but also evolves the society around them.

\section{Conclusion}

Learning style is one of the diversities in the way of students gaining knowledge. It is assured as one of the most effective learning style in interpreting certain 
knowledge into becoming a discussion. The collaboration made will develop the students' interests and self confidence in delivering and elaborating their ideas regarding any issues they had been given to discuss. Students are more oriented to self-direction learning, as they gained various life experience which is one of the richest sources of learning. Apart from that, students within the higher level would conduct more research and observation-based learning regarding any particular matter. Thus, collaborative learning style is the exact method that helps the students into becoming more mature in making decisions

\section{Conflicts of Interest}

The authors declare no conflicts of interest regarding the publication of this paper.

\section{References}

Abd, A. Z., Razak, \& Azman, N. (2012). Stail Berfikir dan Stail Pembelajaran Pelajar Jururawat: Satu Kajian kes di Kolej Jururawat Murni. AJTLHE, 4, 14-31.

Altun, F., \& Yazici, H. (2010). Learning Styles of the Gifted Students in Turkey. Procedia Social and Behavioral Sciences, 9, 198-202. https://doi.org/10.1016/j.sbspro.2010.12.136

Amir, R. (2007). Stail Berfikir, Stail Pengajaran dan Stail Pembelajaran Pensyarah dan Pelajar UKM. Tesis Dr. Fal., Fakulti Pendidikan, Bangi: Universiti Kebangsaan Malaysia.

Amir, R. (2008). Stail Pengajaran, Stail Pemikiran dan Stail Pembelajaran Pelajar UKM. Tesis Dr. Fal. Bangi: Universiti Kebangsaan Malaysia.

Anitah (2007). Strategi Pembelajaran di SD. Jakarta: Kemdiknas.

Babadogan, C., \& Kilic, G. (2012). Learning Modalities of Sixth Grade Students and the Learning and Teaching Modalities of the English Teachers at Primary Schools. Procedia-Social and Behavioral Sciences, 46, 2467-2471.

https://doi.org/10.1016/j.sbspro.2012.05.504

Baharin, Y., \& Yusop, F. D. (2011). Pembelajaran Kolaboratif Menggunakan Blog Dalam Pembelajaran Mata Pelajaran Ekonomi Asas. Jurnal Pendidikan, 31.

Bakar, N. A. \& Iksan, Z. H. (2015). Perbandingan Kelas Terbuka dan Sesi Refleksi dalam Pelaksanaan "Lesson Study" di Antara Jepun dan Malaysia. Proceeding of the 7th International Seminar on Regional Education, 2 November 2015, 5-7.

Basmeih, A. M. (2001). Tafsir Pimpinan Ar-Rahman Kepada Pengertian Al-Quran (30) Juz. Kuala Terengganu: Percetakan Yayasan Islam Terengganu. Sdn Bhd.

Bayrak, B. K. (2012). A Study on Learning Style of Secondary Student's According to Gender and Class Level. Procedia-Social and Behavioral Sciences, 46, 843-847.

Butch, K., \& Bartley, S. (2002). Learning Styles and Training Delivery Mode Preference. Journal of Workplace Learning, 14, 5-10. https://doi.org/10.1108/13665620210412795

Felder, R. M., \& Brent, R. (1996). Navigating the Bumpy Road to Student-Centred Instruction. College Teaching, 44, 43-47. https://doi.org/10.1080/87567555.1996.9933425

Grasha, A. F. (1996). Teaching with Styles: A Practical Guide to Enhance Learning by Understanding Learning and Teaching Styles. Pittsburgh: Alliance Publishers.

Guolla, M. (1999). Assessing the Teaching Quality to Student Satisfaction Relationship: Applied Customer Satisfaction Research in the Classroom. Journal of Marketing Theory and Practice, 87-97. https://doi.org/10.1080/10696679.1999.11501843 
Halic, O., Lee, D., Paulus, T., \& Spence, M. (2010). To Blog or Not to Blog: Student Perceptions of Blog Effectiveness for Learning in a College-Level Course. The Internet and Higher Education, 13, 206-213. https://doi.org/10.1016/j.iheduc.2010.04.001

Hasanuddin (2009). Profil Stail Berfikir, Stail Pengajaran Dan Stail Pembelajaran Dalam Kalangan Pensyarah Dan Pelajar. Tesis Dr. Fal, Bangi: Universiti Kebangsaan Malaysia.

Hong, J. C., Yu, K. C., \& Chen, M. Y. (2011). Collaborative Learning in Technological Project Design. International Journal of Technology and Design Education, 21, 335-347. https://doi.org/10.1007/s10798-010-9123-7

Ibrahim, J. (2006). Gaya pengajaran guru bahasa Daerah Hulu Langat Satu kajian tinjauan. Kertas Projek Sarjana Pendidikan, Bangi: Universiti Kebangsaan Malaysia.

Jasmi, K. A., Ibrahim, N., \& Ilias, M. F. (2012). Gaya Pengajaran Guru dalam Pengajaran dan Pembelajaran Pendidikan Islam. International Seminar on Teacher and Islamic Education (SEAPPI2012) Senai, 211-223.

Krejcie, R. V., \& Morgan, D. W. (1970). Determining Sample Size for Research Activities. Educational and Psychological Measurement, 30, 607-610. https://doi.org/10.1177/001316447003000308

Mahamod, Z., Yusoff, N. M. R. N., \& Ibrahim, J. (2009). Perbandingan gaya pengajaran guru Bahasa Melayu dan guru Bahasa Inggeris. Jurnal Pendidikan Malaysia, 34, 67-92.

Md Nawi, N. H. (2011). Pengajaran dan Pembelajaran; Penelitian Semula Konsep-Konsep Asas Menurut Perspektif Gagasan Islamisasi Ilmu. Kongres Pengajaran dan Pembelajaran UKM.

Newby, T. J., Stepich, D. A., Lehman, J. D., \& Russell, J. D. (2000). Instructional Technology for Teaching and Learning. New Jersey: Prentice Hall.

Sang, M. S. (2011). Psikologi untuk Pengajaran dan Pembelajaran. Malaysia: Penerbitan Multimedia Sdn. Bhd.

Triman, A. (2014). Personaliti dan Gaya Pembelajaran dalam Kalangan Pelajar Pintar Cerdas. Tesis Sarjana, Fakulti Pendidikan, Bangi: Universiti Kebangsaan Malaysia.

Wilson, K., \& Lizzio, A. (1997). The Development, Validation and Application of the Course Experience Questionnaires. Studies in Higher Education, 22, 33-63.

https://doi.org/10.1080/03075079712331381121

Yusuf, S. A. M. (2016). Gaya Pembelajaran Dan Pengajaran Pendidikan Islam Di Universitas Islam Negeri Ar-Raniry Aceh Indonesia. Tesis Sarjana, Fakulti Pendidikan, Bangi: Universiti Kebangsaan Malaysia. 